Jurnal Pemberdayaan: Publikasi Hasil Pengabdian kepada Masyarakat

Vol. 3, No. 2, Agustus 2019, Hal. 179-184

ISSN: 2580-2569; e-ISSN: 2656-0542

DOI: https://doi.org/10.12928/jp.v3i2.766

\title{
Edukasi kesehatan konsumsi sayur dan buah, serta pengelolaan sampah pada anak-anak SD Negeri Kempong
}

\author{
Dessy Pranungsari, Indra Chaerul Anwar, Samsul Maarifudin, Viki Arisandi \\ Fakultas Psikologi Universitas Ahmad Dahlan, Jl. Kapas, Semaki, Yogyakarta \\ dessy.pranungsari@psy.uad.ac.id
}

\begin{abstract}
ABSTRAK
SD Negeri Kempong merupakan satu-satunya sekolah dasar yang terletak di Dusun Kempong, Banjaroyo, Kalibawang, Kulon Progo. Edukasi diikuti sebanyak 25 siswa dari total 64 siswa di SD Kempong. Konsumsi sayur dan buah merupakan salah satu syarat dalam memenuhi menu gizi seimbang. Konsumsi sayur dan buah sangat penting untuk dilakukan oleh anak-anak di setiap kali makan. Konsumsi sayur dapat mempengaruhi tingkat pertumbuhan dan perkembangan anak, khususnya yaitu pada usia 7-9 tahun. Pengetahuan tentang perbedaan sampah organik dan anorganik juga merupakan suatu hal yang penting untuk diajarkan kepada siswa. Hal ini dilakukan dengan tujuan agar siswa mampu menjaga lingkungan dan mengetahui manfaat dari sampah organik dan anorganik. Dengan memberikan edukasi selama 2 hari (12 dan 13 Februari 2019) tentang pentingnya konsumsi sayur dan buah serta perbedaan sampah diharapkan anak-anak dapat mengonsumsi sayur, buah setiap harinya dan dapat menjaga lingkungan agar tetap bersih.
\end{abstract}

Kata Kunci: Penyuluhan, Konsumsi Sayur dan Buah, Pengelolaan Sampah, SD Negeri Kempong.

\begin{abstract}
SD Negeri Kempong is the only elementary school located in Dusun Kempong,Banjaroyo, Kalibawang, Kulon Progo. The education was attended by 25 students from a total of 64 students at School. Consumption of vegetables and fruit is one of the requirements in fulfilling a balanced nutritional menu. Consumption of vegetables and fruit is very important to be done by children at every meal. Consumption of vegetables can affect the growth and development of children, especially at the age of 7-9 years. Knowledge about the difference between organic and anorganic waste is also an important thing to be taught to students. This is done with the aim that students are able to protect the environment and know the benefits of organic and inorganic waste. By providing education for 2 days (12 and 13 February 2019) about the importance of vegetable and fruit consumption and the difference in waste it is hoped that children can consume vegetables, fruits every day and can keep the environment clean.
\end{abstract}

Keywords: Educate, Vegetable and Fruit Consumption, Waste Management, SD Negeri Kempong

\section{PENDAHULUAN}

Desa Banjaroyo merupakan salah satu lokasi yang dipilih oleh Lembaga Penelitian dan Pengabdian kepada Masyarakat (LPPM) untuk melaksanakan program KKN UAD 71 Reguler. Desa Banjaroyo masuk ke dalam Kecamatan Kalibawang, Kabupaten Kulon Progo. Pelaksanaan KKN Divisi XVII.B bertempat di salah satu dusun dari desa Banjaroyo, dusun tersebut adalah dusun Kempong yang bertempat di SD Negeri Kempong. Pelaksanaan KKN khususnya di dusun Kempong banyak memiliki potensi, di antaranya prasarana lingkungan dan pemukiman, prasarana ekonomi, prasarana SDM, program kesehatan, program pendidikan, serta sebagai 
potensi non fisik yang dapat dioptimalisasikan dalam usaha untuk pembangunan guna meningkatkan perekonomian dan pengetahuan untuk masyarakat dusun Banjaroyo.

Program kerja bersama yang diselenggarakan oleh KKN Divisi XVII B Desa Banjaroyo yang beranggotakan 27 mahasiswa yang dibagi dalam 3 unit. Salah satu program unggulan dari KKN Divisi XVII B Desa Banjaroyo adalah program "Edukasi Kesehatan Mengenai Konsumsi Sayur dan Buah dan perbedaan sampah organik dan anorganik".

Sayur dan buah merupakan sumber zat gizi makro yang sangat bermanfaat bagi tubuh, karena kedua komponen gizi tersebut sangat penting dalam proses metabolisme tubuh sebagai zat pengatur dan antibodi juga bermanfaat untuk menurunkan insiden terkena penyakit kronis. Sayur dan buah merupakan makanan penting yang harus dikonsumsi setiap kali makan. Tidak hanya bagi orang-orang dewasa, sayur dan buah sangat penting untuk dikonsumsi sejak usia anak-anak, karena pada usia tersebut merupakan masa emas untuk pertumbuhan dan perkembangan bagi anak-anak.(Permenkes, 2014)

WHO merekomendasikan konsumsi sayur dan buah sebanyak 400 gram perhari. Menurut Pedoman Gizi Seimbang pada tahun 2014, anak balita dan anak usia sekolah dianjurkan untuk mengonsumsi sayuran dan buah-buahan sebanyak 300-400 gram yang terdiri dari 250 gram sayur (setara dengan 3-5 porsi atau 2,5 gelas sayur setelah dimasak dan ditiriskan) dan 150 gram buah (setara dengan 2-3 porsi atau 3 buah pisang ambon ukuran sedang atau 1,5 potong pepaya ukuran sedang atau 3 buah jeruk ukuran sedang) (WHO, 2003).

Sampah adalah barang yang dianggap sudah tidak terpakai dan dibuang oleh pemilik/pemakai sebelumnya, tetapi bagi sebagian orang masih bisa dipakai jika dikelola dengan prosedur yang benar.(Nugroho, 2013). Menurut Nugroho dalam buku Panduan Membuat Pupuk Kompos cair (2013), berdasarkan sifatnya sampah dapat digolongkan menjadi beberapa sifat, antara lain; sampah organik dan sampah anorganik. Sampah organik, yaitu sampah yang mudah membusuk seperti sisa makanan, sayuran, daun-daun kering, dan sebagainya. Sampah ini dapat diolah lebih lanjut menjadi kompos. Sampah anorganik, yaitu sampah yang tidak mudah membusuk, seperti plastik wadah pembungkus makanan, kertas, plastik mainan, botol dan gelas minuman, kaleng, kayu, dan sebagainya. Sampah ini dapat dijadikan sampah komersil atau sampah yang laku dijual untuk dijadikan produk lainnya. Beberapa sampah anorganik yang dapat dijual adalah plastik wadah pembungkus makanan, botol dan gelas bekas minuman, kaleng, kaca, dan kertas.

Menurut (Notoatmodjo, 2005) edukasi merupakan pengalaman belajar untuk mempengaruhi sikap, dan perilaku. Oleh karena itu, pengetahuan mengenai konsumsi sayur, buah dan perbedaan sampah organik dan anorganik sangat penting untuk diterapkan pada usia anak-anak. Mengonsumsi sayur dan buah berwarna sebanyak lima porsi atau lebih adalah bagian penting dalam pola hidup sehat. Hal ini disebabkan sayur dan buah yang berwarna memberikan berbagai macam vitamin, mineral, serat dan fitokimia yang digunakan oleh tubuh untuk menjaga kesehatan, melindungi tubuh dari efek penuaan, serta mengurangi resiko terkena beberapa jenis kanker. Pengetahuan tentang perbedaan sampah organik dan anorganik sangat penting agar anakanak dapat memanfaat sampah dan mendaur ulang sampah menjadi sesuatu yang berharga dan dapat menjaga lingkungan agar tetap bersih, rapi dan sehat.

\section{METODE}

Edukasi kesehatan mengenai konsumsi sayur dan buah serta Pengelolaan sampah dilaksanakan di SD Negeri Kempong. Kegiatan tersebut diselenggarakan pada tanggal 12 dan 13 Februari 2019. Hari pertama digunakan untuk materi pengantar dan hari kedua untuk kegiatan 
edukasi melalui permainan. Sasaran dalam kegiatan edukasi ini yaitu siswa-siswi kelas 2 dan 3 yang berjumlah 25 siswa. Tujuan penyuluhan tersebut diharapkan siswa-siswa sekolah dasar khususnya kelas 2 dan kelas 3 dapat mengetahui pentingnya konsumsi sayur dan buah dan pengelolaan sampah. Sebelum dilakukan edukasi siswa dan siswi terlebih dahulu diberi soal pre test untuk mengetahui pengetahuan mengenai sayur dan buah. Setelah diberikan penyuluhan siswa dan siswi juga diberikan soal post test guna mengetahui perbedaan pengetahuan antara sebelum penyuluhan dan sesudah penyuluhan. Rincian metode pelaksanaan tersaji pada tabel 1 .

Tabel 1. Metode pelaksanaan edukasi konsumsi sayur dan buah pada anak-anak

\begin{tabular}{|c|c|c|c|}
\hline No $\quad$ Metode & Nama Kegiatan & $\begin{array}{l}\text { JKEM } \\
\text { (menit) }\end{array}$ & $\begin{array}{l}\text { Jumlah } \\
\text { mahasiswa } \\
\text { yang terlibat }\end{array}$ \\
\hline 1. Penyuluhan & \begin{tabular}{l}
\multicolumn{2}{l}{ Penyelenggaraan } \\
penyuluhan konsumsi \\
sayur dan buah \\
Penyuluhan mengenai \\
pengelolaan sampah \\
organic dan anorganik
\end{tabular} & 100 & 9 \\
\hline 2. Praktik/Games & $\begin{array}{l}\text { Praktik membedakan ciri- } \\
\text { ciri buah dan sayur } \\
\text { beserta manfaatnya } \\
\text { Praktek membedakan } \\
\text { sampah organic dan } \\
\text { anorganik }\end{array}$ & 100 & 9 \\
\hline
\end{tabular}

\section{HASIL, PEMBAHASAN DAN DAMPAK}

Gambaran kegiatan tersaji pada Gambar 1-4. Hasil pretest dan posttest kegiatan edukasi kesehatan mengenai konsumsi sayur, buah dan mengenai pengelolaan sampah pada anak-anak Kelas 2 dan 3 SD Negeri Kempong tersaji pada Tabel 1.

Berdasarkan hasil pada Tabel 1 diperoleh hasil selisih dengan angka 5 sebanyak 4 siswa. Hasil selisih dengan angka 10 sebanyak 3 siswa. Hasil selisih dengan angka 15 sebanyak 18 siswa. Nilai selisih paling besar dengan angka 15 artinya pengetahuan siswa setelah diberikan edukasi meningkat dibandingkan dengan sebelum dilakukannya edukasi. Nilai selisih paling rendah dengan angka 5 artinya pengetahuan siswa setelah diberikan edukasi meningkat namun tidak terlalu tinggi dibandingkan dengan sebelum dilakukannya edukasi. 


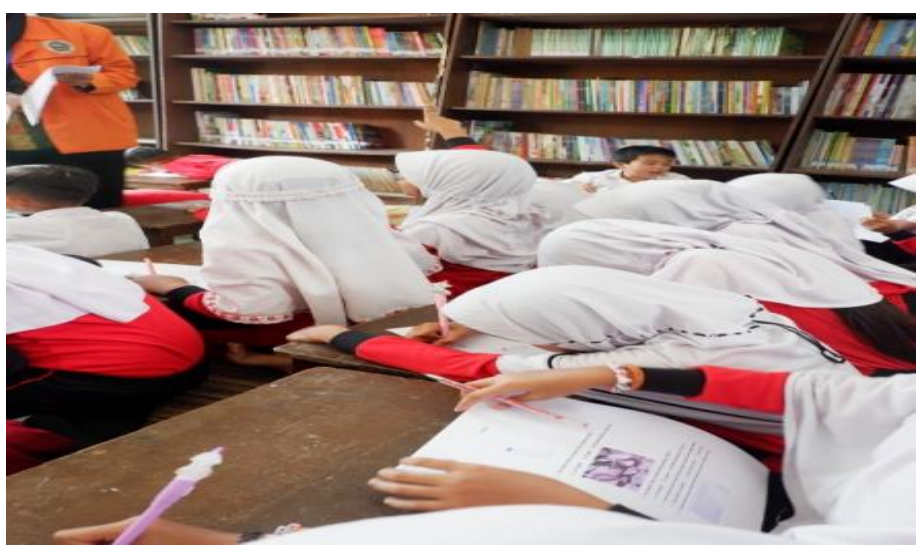

Gambar 1. Kegiatan pretest penyuluhan konsumsi sayur pada siswa SD

Peningkatan nilai selisih antara sebelum dilakukan edukasi dengan setelah dilakukan edukasi menunjukkan pengetahuan anak-anak mengenai konsumsi sayur, buah dan pengelolaan sampah mengalami peningkatan. Hal ini dapat dilihat pada table 2. dari hasil selisih yang telah diperoleh dari pemberian pretest dan posttest kepada siswa SDN Kempong kelas 2 dan 3. Peningkatan hasil posttest siswa dikarenakan adanya kegiatan dari edukasi yang sangat bermacam-macam, sehingga membuat suasana pembelajaran menjadi lebih menarik dan menyenangkan. Gambaran suasana saat pemberian materi terlihat pada Gambar 2.

Tabel 2. Hasil pretest dan posttest edukasi kesehatan di SDN Kempong

\begin{tabular}{cccc}
\hline No. & Skor Pretest & Skor Postest & Peningkatan skor \\
\hline 1. & 45 & 60 & 15 \\
2. & 50 & 55 & 5 \\
3. & 60 & 65 & 5 \\
4. & 75 & 80 & 5 \\
5. & 55 & 70 & 15 \\
6. & 45 & 60 & 15 \\
7. & 55 & 65 & 10 \\
8. & 55 & 70 & 15 \\
9. & 50 & 65 & 15 \\
10. & 55 & 70 & 15 \\
11. & 70 & 85 & 15 \\
12. & 75 & 90 & 15 \\
13. & 75 & 85 & 10 \\
14. & 60 & 75 & 15 \\
15. & 65 & 75 & 10 \\
16. & 60 & 75 & 15 \\
17. & 65 & 80 & 15 \\
18. & 60 & 75 & 15 \\
19. & 65 & 80 & 15 \\
20. & 70 & 85 & 15 \\
21. & 60 & 75 & 15 \\
22. & 65 & 70 & 5 \\
23. & 60 & 75 & 15 \\
24. & 65 & 80 & 15 \\
25. & 70 & 85 & 15 \\
\hline
\end{tabular}




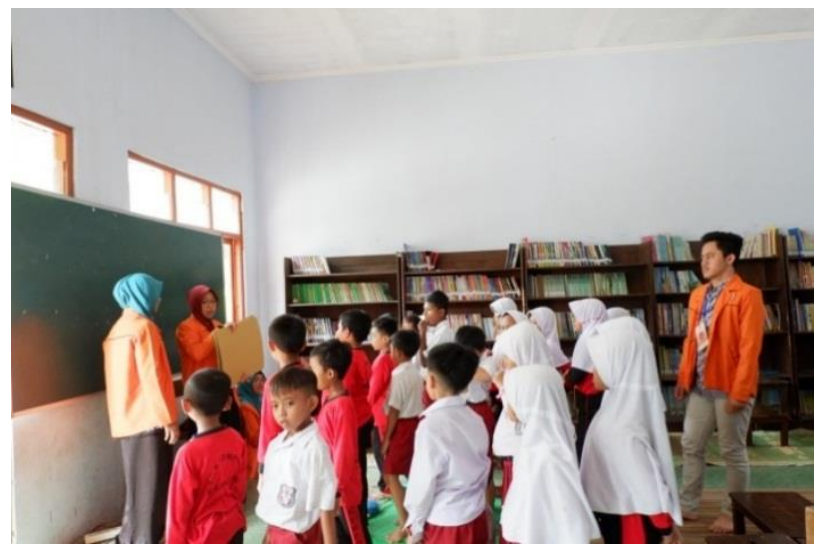

Gambar 2. Pemberian materi edukasi konsumsi sayur pada anak

Kegiatan edukasi kesehatan ini meliputi penyuluhan dan kegiatan games untuk meningkatkan ketertarikan siswa-siswi dalam melakukan pembelajaran mengenai konsumsi sayur dan buah. Penyuluhan dilakukan di dalam ruang perpustakaan. Games yang dilakukan menggunakan metode estafet. Setiap kelompok terdiri dari 5 siswa, kemudian masing-masing memilih ciri-ciri maanfaat sayur, buah yang sudah tersedia serta membedakan sampah organik dan an organik. Banyak hal positif yang dapat diambil dari kegiatan ini. Salah satunya yaitu siswa-siswi menjadi senang karena dapat bermain bersama-sama, dan kemampuan belajar secara kelompok dapat meningkat. Hal ini sejalan dengan penelitian Ichsan, dkk (2018) yang menunjukkan terdapat peningkatan pengetahuan tentang pentingnya sayuran bagi anak-anak yang bermakna setelah mengikuti sesi penyuluhan.Gambaran metode games pada edukasi konsumsi sayur terlihat pada Gambar 3.

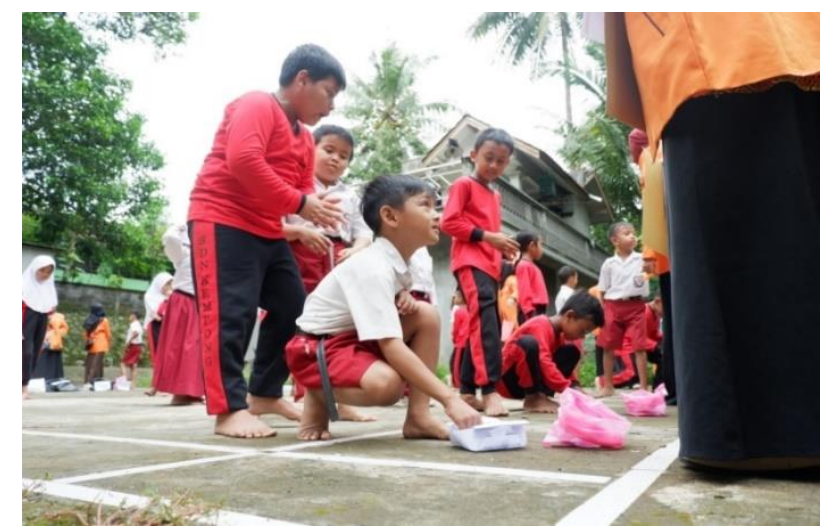

Gambar 3. Games mengenai sampah, konsumsi sayur dan buah

Pendidikan kesehatan melalui penyuluhan dan games dapat merubah konsumsi sayur karena cerita merupakan alat yang ampuh untuk menyampaikan pengajaran, pesan maupun teguran. Ketika anak tahu mengenai manfaat konsumsi sayur anak akan sadar dan tertarik untuk mencoba mengonsumsinya. Pengenalan dan pemaparan sayur secara berulang-ulang saat usia dini mampu meningkatkan kesukaan anak. Namun sayangnya tidak semua orangtua mengenalkan anak pada sayur, sehingga pengetahuan anak tentang sayur juga kurang

Sampah organik merupakan sampah yang sebagian besar tersusun oleh senyawa-senyawa organik, dan berasal dari sisa-sisa tumbuhan (sayur, buah, daun, kayu, dll.), hewan (bangkai, kotoran, bagian tubuh seperti tulang, dll). Sampah ini bersifat dapat terurai (degradable) sehingga dalam waktu tertentu akan berubah bentuk dan dapat menyatu kembali dengan alam. 
Sampah an-organik ialah sampah yang sebagian besar tersusun oleh senyawa-senyawa anorganik, dan berasal dari sisa industri, seperti plastik, botol / kaca, kaleng, logam, dll.. Sampah an-organik umumnya bersifat sukar terurai/sukar lapuk dan tidak lapuk (non-degradable) sehingga akan selalu dalam bentuk aslinya di alam. (Sudrajat, 2006)

Edukasi mengenai pengelolaan sampah organik dan an-organik dapat meningkatkan kepedulian dalam memilah sampah. Hal ini sejalan dengan penelitian Laifatul, dkk (2018) yang menunjukkan adanya peningkatan pemilahan sampah responden di Dusun Krajan RT 002 RW 005 Desa Kemuningsari Lor Kecamatan Panti Kabupaten Jember sebelum pelatihan pemilahan sampahdalam kategori kurang dan setelah pelatihan dalam kategori baik.

\section{SIMPULAN}

Program pengabdian berupa edukasi kesehatan mengenai konsumsi sayur, buah dan sampah kelas 2 dan 3 SD Negeri Kempong telah dilakukan dan partisipasi siswa sangat tinggi. Tingkat pengetahuan siswa tentang sayur dan sampah meningkat dengan terselenggaranya kegiatan edukasi kesehatan ini.

\section{DAFTAR PUSTAKA}

Ichsan, B, dkk., (2015), Penyuluhan Pentingnya Sayuran bagi Anak-anak di TK Aisyiyah Kwadungan, Trowongsan, Malangjiwan, Colomandu, Karanganyar, Jawa Tengah. Jurnal Warta. 18 (1 ): 29-35.

Laifatul, F.N, dkk., (2018), Pengaruh Sosialisasi Pemilahan Sampah Organik dan Non Organik serta Manajemen Sampah terhadap Penurunan Volume Sampah di Dusun Krajan Desa Kemuningsari Lor Kecamatan Panti Kabupaten Jember. The Indonesian Journal of Health Science. Edisi Khusus: 84-87.

LPM UAD.,(2018), Pedomandan Panduan Kuliah Kerja Nyata, Yogyakarta: LPM UAD

Notoatmodjo, S., (2005), Promosi Kesehatan Teori dan Aplikasi. Jakarta: Rineka Cipta

Nugroho, P. (2013), Panduan Membuat Kompos cair, pustaka baru Press, Jakarta

Permenkes., (2014), Pedoman Gizi Seimbang. http://hukor.kemkes.go.id. Diakses 20 Agustus 2019

Sudrajat, R,. (2006), Mengolah Sampah Kota. Depok: Penebar Swadaya.

World Health Organization (WHO)., 2003, Initiative to Promote fruit and vegetables for Health Worldwide. http://www.who.int/dietp. Diakses 16 Maret 2019 